\title{
Event kind formation within the VP: Comparing Russian factual imperfectives and German adjectival passives
}

\author{
Berit Gehrke (CNRS-LLF / Paris Diderot) \& Olav Mueller-Reichau (Leipzig) ${ }^{1}$
}

Formal Description of Slavic Languages (FDSL) 10, Leipzig, December 5-7, 2013

\section{Introduction}

- Carlson (2003), observing the behavior of weak indefinites in English:

Something fundamentally different goes on within the VP that does not go on "above" the VP - it is only information about the types/properties that appears there and not information about (contingent) particulars.

- We arrived at similar conclusions observing:

- Russian factual imperfectives

- German adjectival passives

\section{- Our proposal:}

- Verbs lexically denote predicates of event kinds.

- Event kinds get instantiated when the VP is embedded under aspectual-temporal structure.

- Under certain circumstances, the event can remain in the kind domain.

- The Russian general-factual use of the imperfective (ipf) aspect (obščefaktičeskoe značenie) (see Glovinskaja 1981, 1989; Padučeva 1996; Grønn 2003, among many others):

- Several subtypes of this use have been identified; we focus here on the use of an ipf verb form to refer to a completed situation, as in (1). ${ }^{2}$

$\rightarrow$ We will ignore presuppositional factual ipsf, being concerned exclusively with existential factual ipfs (cf. Grønn 2003).

- The factual use of ipf comes close to the interpretation of the perfective (pf) aspect (2b).

(1) U menja nedavno umer otec. Ja točno znaju, čto on sostavljal zaveščanie goda at me recently died.PF father I sure know that he composed.IPF testament years dva nazad, no ne mogu najti dokument. two before but not can find document 'My father died recently. I know for sure that he has made his last will about two years ago, but I cannot find the document.'
a. Moj otec sostavljal zaveščanie.
my father composed.IPF testament
(i) 'My father was writing his will.'
(ii) 'My father has made his will.'
b. Moj otec sostavil zaveščanie.
my father composed.PF testament
'My father made/has made his will.'

ONGOING: ok

\footnotetext{
${ }^{1}$ This research has been supported by grants to the following projects: JCI-2010-08581 (Spanish Ministry of Science and Innovation), FFI2012-34170 (Spanish Ministry of Economy and Competitiveness), and DFG grant MU 3503/1-1.

${ }^{2}$ Throughout we use the present perfect to translate factual ipfs.
} 
- The German adjectival passive (Zustandspassiv) (see Kratzer 1994, 2000; Rapp 1997; Maienborn 2007a, among many others):

- The combination of the auxiliary sein 'be' with a past passive participle to ascribe a stative property to an entity, which is often perceived as the result of an event (3a).

- The interpretation is close in meaning to a perfect verbal passive (which combines the copula werden 'become' with a past passive participle) $(3 b){ }^{3}$
a. Die Tür ist geschlossen.
the door is closed
'The door is closed.'

b. Die Tür ist geschlossen worden.

the door is closed become.PRT

'The door has been closed.'

\section{- We argue that both involve event kinds.}

- Factual ipfs: The event description supplied by the VP is a kind due to a specific information structure: the claim about the existence of the event is in focus (Padučeva 1996).

- Adjectival passives: The event description remains in the kind domain due to the adjectivisation of the VP (Gehrke 2011, 2012, 2013, to appear). ${ }^{4}$

\section{Empirical peculiarities common to both}

\subsection{No event uniqueness}

- It has been noted that uniqueness implies pf in Russian (e.g. Dickey 2000).

- Factual ipfs are incompatible with an event property describing a necessarily unique event token (4a); such a property requires the pf (4b) (examples from Grønn 2003) (orig. Vogeleer 1993).
a. *Ty el dve konfety, kotorye ležali na stole? you ate.IPF 2 candy that laid on table
b. Ty s"el dve konfety, kotorye ležali na stole? you ate.PF 2 candy that laid on table 'Did you eat [have you eaten] the two candies, which were lying on the table?'

- A unique event token is also incompatible with the German adjectival passive (5a), whereas the verbal passive is fine $(5 b)$.

a. *Der Kettenanhänger ist aus dem Bernsteinstück gemacht, das ich an der the necklace pendant is out the amber piece made which I at the Ostsee gefunden habe.

Baltic Sea found have

b. Der Kettenanhänger ist aus dem Bernsteinstück gemacht worden, das the necklace pendant is out the amber piece made become.PART which ich an der Ostsee gefunden habe.

I at the Baltic Sea found have

'The necklace pendant has been made out of the amber piece that I found at the Baltic Sea.'

\footnotetext{
${ }^{3}$ See Rapp (1996, 1997); Maienborn (2007a) and literature cited therein for arguments why the adjectival passive cannot be treated as a case of werden-ellipsis in a perfect verbal passive. Throughout we will gloss the auxiliary werden as 'become', even if English become does not have this use.

${ }^{4}$ The event kind approach to adjectival passives has been taken up by Gese (2011); Maienborn and Geldermann (2013).
} 


\subsection{The time of the event culmination cannot be indicated.}

- Under the factual interpretation of the ipf, the time of (the completion/culmination of) the event cannot be explicated by a specific temporal adverbial.

- As soon as such a specific temporal adverbial is added, the completed event interpretation is no longer available (6a).

- With pf aspect, the completion can be temporally specified without reservation (6b).

a. Moj otec sostavljal zaveščanie včera v 3 časa.

my father composed.IPF testament yesterday in 3 hour

$=$ 'My father was writing his will yesterday at 3.'

ONGOING: ok

$\neq$ 'My father has made his will yesterday at 3.'

COMPLETED: *

b. Moj otec sostavil zaveščanie včera v 3 časa.

my father composed.PF testament yesterday in 3 hour

'My father made his testament yesterday at 3.'

- Only temporal adverbials are allowed that provide a general, longer time span within which the event is (vaguely) placed; cf. (7) (from Grønn 2003).

V detstve ja čital 'Čudesa Indii'.'

in childhood I read.IPF wonders India.GEN

'In my childhood I read 'The Wonders of India'.'

- German adjectival passives refer to states; the underlying event lacks temporal location (cf. Rapp 1996, 1997).

- Temporal frame adverbials are unacceptable with the adjectival passive (8a) (example from von Stechow 1998), but fine with the verbal passive (8b).
a. *Der Computer ist vor drei Tagen repariert. the computer is before three days repaired
b. Der Computer ist vor drei Tagen repariert worden. the computer is before three days repaired become.PRT 'The computer has been repaired three days ago.'

\subsection{The place of the event culmination cannot be indicated.}

- Although the event is completed, factual ipfs do not tolerate spatial adverbials that would identify the "place of completion" (9a); this is in clear contrast to the situation with pf (9b).
a. Moj otec sostavljal zaveščanie $\mathrm{v}$ poezde.
my father composed.IPF testament in train
$=$ 'My father was writing his will on the train.'
$\neq$ 'My father has made his will on the train.'
b. Moj otec sostavil zaveščanie $\mathrm{v}$ poezde.
my father composed.PF testament in train
'My father wrote his will on the train.'

ONGOING: ok

COMPLETED: *

- Locating a particular event by means of a spatial adverbial is also bad in German adjectival passives (10a) (example from Gehrke 2011), ${ }^{5}$ but not in verbal passives (10b).

\footnotetext{
${ }^{5}$ The hash mark indicates (marginal) acceptability if the PP modifies the state, so that the spatial frame creates some kind of temporal frame for the state itself (see Maienborn 2007b).
} 
a. \#Die Reifen sind in der Garage aufgepumpt.

the tires are in the garage inflated

b. Die Reifen sind in der Garage aufgepumpt worden.

the tires are in the garage inflated become.PRT

'The tires have been inflated in the garage.'

- The ban with adjectival passives is strictly on spatial PPs that locate an event particular.

- Other spatial PPs are possible, especially those that can be viewed as manner modifiers to specify a subkind of event, e.g. (11). ${ }^{6}$

(11) Die Pizza war in einem Steinofen gebacken.

the pizza was in a stone pot baked

'The pizza was baked in a stone oven.'

- The same is true for Russian; cf. (12) (from the internet).
Vse v norme, - usmexalsja Otec Moxovik, - v ix gody ja davno all in norm smiled father Moxovik in their years I long nočeval $\quad \mathrm{v}$ lesu.
spent-the-night.IPF in forest
"No problem', smiled Father Mokhovik, 'at their age, I have long since spent the night in the woods."

\subsection{Discourse transparency}

- With factual ipf, pronominal anaphora to refer back to the objects of "permanent target state predicates" (Grønn 2003) are not good (13a).

- With pf, such anaphora are good without reservation (13b).

$$
\begin{aligned}
& \text { a. Ja uže el tarakana }{ }_{1} \text {. *A teper' mne } \text { ego }_{1} \text { žalko. } \\
& \text { I already ate.IPF cockroach.ACC and now me him sorry }
\end{aligned}
$$

b. Ja uže s"el tarakana ${ }_{1}$. A teper' mne ego o $_{1}$ žalko.

I already ate.PF cockroach.ACC and now me him sorry

'I have already eaten a/the cockroach. And now I feel sorry for it.'

- Arguably, the introduction of a discourse referent by tarakana would render the event description unique, which calls for pf (see above). ${ }^{7}$

- In adjectival passives we also find discourse opaque noun phrases:

- An indefinite NP in a by- or with-phrase does not introduce a discourse referent as it cannot be picked up by pronominal anaphora (14a) (example from Gehrke 2013).

- The verbal passive counterpart does provide an antecedent for the pronoun (14b).

a. Das Bild ist von [einem Kind $]_{1}$ angefertigt. ${ }^{*} \mathrm{Es}_{1}$ hat rote Haare. the drawing is by a child produced it has red hairs

b. Das Bild ist von [einem Kind $]_{1}$ angefertigt worden. Es ${ }_{1}$ hat rote Haare. the drawing is by a child produced become.PART it has red hairs 'The drawing has been produced by a child. He/she has red hair.'

\footnotetext{
${ }^{6}$ Maienborn (2003) treats such PPs as (event-) 'internal', rather than 'external' modifiers.

${ }^{7}$ See Grønn (2003) for a different proposal in terms of permanence.
} 


\subsection{Adjectival modification}

- Not any adjectival modification of the internal argument noun yields an (easily) acceptable factual ipf. This "sensitivity to lexical meaning" is not found with pf aspect.

- (15a) with berezovyj 'birch-' lends itself to a plausible factual ipf, but not with želtyj 'yellow'; the latter works only in a context in which the drinking of yellow juice is somehow pre-established as a category.

- This restriction is not found with the pf $(15 b)$.
a. Ja uže pil $\quad\{$ berezovyj / \#želtyj\} sok.
I already drank.IPF birch- yellow juice.ACC
'I have already drunk \{birch / \#yellow $\}$ juice.'
b. Ja uže vypil želtyj sok.
I already drank.PF yellow juice.ACC
'I have already drunk the yellow juice.'

- Similar restrictions on adjectival modification are found with the complements of event-related by- and with-phrases with German adjectival passives (16).

- The addition of the adjective in (16a) does not make a sound adjectival passive.

- The corresponding verbal passive works without reservation (16b).

a. Das Bild ist von einem (\#blonden) Kind gemalt.

the painting is by a blond child painted

b. Das Bild ist von einem blonden Kind gemalt worden.

the painting is by a blind child painted become.PART

'The drawing has been painted by a blond child.'

- The modified example in (16a) becomes acceptable if it is supported by a context that makes clear that the modification is understood as kind or type modification (17).

(17) "Das Bild kann bleiben. Es ist von einem blonden Kind gemalt", sagte der Nazi. the painting can stay it is by a blond child painted said the Nazi

- Clear cases of kind/type modifiers are acceptable also out of context, as in (18).

(18) Der Brief ist mit roter Tinte geschrieben.

the letter is with red ink written

\subsection{Referentiality effects on VP-internal nominals}

- It has been noted that the objects of factually used ipf verbs, but not of pf verbs, often lack a strongly referential reading (see Grønn 2003, 240ff. for discussion).

- The object noun phrase in (19a) cannot get a specific reading (ex. from Padučeva 1996).

- This is not the case with the object noun phrase of the pf counterpart (19b).
a. Ty (kogda-nibud') razbival cennuju vazu?
you sometimes broke.IPF valuable vase.ACC
'Have you (ever) shattered a valuable vase?'
b. Ty razbil cennuju vazu?
you broke.PF valuable vase. ACC
'Have you shattered the valuable vase?' 
- Similar with NPs in event-related modifiers of German adjectival passives (cf. Gehrke to appear):

- We find a large number of indefinite and bare nominals (20), whereas (strong) definite NPs are usually unacceptable (21a).

- No such restriction is found with the verbal passive (21b).

(20) Der Brief ist mit Tinte / (einem) Bleistift geschrieben.

the letter is with ink / (a) pencil written

'The letter is written with ink / (a) pencil.'

(21) a. *Der Brief ist mit der Tinte geschrieben.

the letter is with the ink written

b. Der Brief ist mit der Tinte geschrieben worden.

the letter is with the ink written become.PART

'The letter has been written with the ink.'

NB Some speakers find (22) not so bad.

(22) ?Der Brief ist mit dem Bleistift geschrieben.

the letter is with the pencil written

'The letter is written with the pencil.'

$\rightarrow$ For (22) to be possible at all, the definite NP must be read as a weak definite (see Carlson, Sussman, Klein, and Tanenhaus 2006; Aguilar Guevara and Zwarts 2011, among others).

\subsection{Noteworthiness requirement}

- With factual ipf, the overall context or world knowledge plays an important role.

$\rightarrow$ In a particular context, even NPs can appear that are normally considered as strongly referential are allowed.

- For example, (23) has a factual reading, because there is something noteworthy about the event of 'shaving the president'.

$$
\text { Parikmaxer bril prezidenta. }
$$

hairdresser shaved.IPF president
a. 'The hairdresser was shaving the president.'
ONGOING: ok
b. 'The hairdresser has shaved the president.'
COMPLETED: ok

- Since it lacks noteworthiness, (24) is difficult to construe as a factual ipf.
Parikmaxer bril
klienta.
hairdresser shaved.IPF client

a. 'The hairdresser was shaving the client.'

b. 'The hairdresser has shaved the client.'

ONGOING: ok COMPLETED: ?

- Similarly, for proper names:

- Factual ipf are sometimes possible with proper names, but the bearer of the proper name has to be "famous enough"; if this condition is not met, proper names yield questionable results (25) (examples due to Šatunovskij 2009).

$$
\begin{aligned}
& \text { Eto zdanie stroil } \quad \text { Rastrelli / ?I.P. Petrov }\} . \\
& \text { this. ACC building.ACC built.IPF Rastrelli.NOM I.P. Petrov.NOM } \\
& \text { 'This building is built by }\{\text { Rastrelli / ?I.P. Petrov }\} .
\end{aligned}
$$


- The pf version shows no such effect:

(26)

Ėto zdanie postroil I.P. Petrov.

this. ACC building.ACC built.PF I.P. Petrov.NOM

'This building has been built by I.P. Petrov.'

- This "celebrity effect" is also found in German adjectival passives (27) (from Maienborn 2011).

Das Manuskript ist von $\{$ Chomsky / ?Sandberger $\}$ zitiert. the manuscript is by Chomsky Sandberger cited 'The manusript is cited by \{Chomsky / ?Sandberger\}.'

$\rightarrow$ Sandberger should be known to many more people than speaker and hearer, and there should be something noteworthy about the fact that Sandberger cited the manuscript.

- Again, this effect is not found with the verbal passive (28).

Das Manuskript ist von Sandberger zitiert worden.

the manuscript is by Sandberger cited become.PART

'The manusript has been cited by Sandberger.'

\subsection{Summing up}

- Factual ipfs and adjectival passives show striking similarities. Unlike their respective competitors (pf / verbal passive), they display patterns that raise the following questions:

Q1 Why is there a ban on necessarily unique events?

Q2 Why is the culmination time of the event not localizable/identifiable in space and time?

Q3 Why are the respective noun phrases discourse opaque?

Q4 Why do certain noun phrases (at the VP level and below) lack (strong) reference?

Q5 Why can changing the lexical meaning of an adjectival modifier affect acceptibility?

Q6 Why can strong definites and proper names contribute to the event description only if the referent is "famous enough"?

\section{The proposal}

- To provide answers to Q1 - Q6, we propose that both empirical domains under discussion involve event kind formation at the level of VP.

- Russian factual ipfs: The communicative goal of the utterance is to say of this event kind that it is realized.

- German adjectival passives: The communicative goal of the utterance is to say of this event kind that its consequent state kind is realized.

- Our assumptions on unique events (Q1):

- A nominal kind must involve potentially many realizations (e.g. Chierchia 1998).

- We assume this also holds for event kinds, which renders event descriptions that necessarily allow for just a single event token impossible.

- Our assumptions on spatiotemporal localizibility (Q2):

- For Russian factual ipf we assume that even though an event has taken place, the spatiotemporal circumstances of the event are out of focus (see below). 
$\rightarrow$ Explicating the precise temporal or spatial location for the event is mistaken (see 2.2 and 2.3).

- For German, on the other hand, we assume that there is no event token to begin with.

$\rightarrow$ There simply is no temporal or spatial location of an event (see 2.2 and 2.3).

- Our assumptions on discourse opacity and non-referentiality (Q3+Q4):

- For Russian factual ipf we assume that weak reference effects show up in order to avoid uniqueness of the event description, which must be avoided under kind reference.

- For German, on the other hand, we assume a more fundamental story:

$\rightarrow$ Out of context / world knowledge, only weakly or non-referential nominals can participate in an event kind description: discourse opacity, no token modification, ban on strongly referential nominals $(2.4,2.5,2.6)$.

$\rightarrow$ If, on the other hand, such participants can form part of the event kind description (qua noteworthiness), the examples improve (2.7)

- Our assumptions on the influence of the lexical choice of an adjective (Q5):

- An event kind is a unique entity; it is the entity which is named by the infinitival form of a verb/VP (just like an ordinary individual is the entity named by a proper name).

$\Rightarrow$ It is inherently definite.

- Its existence in the common ground is presupposed, i.e. the event kind must be wellestablished in the background knowledge.

- A change of the adjective may lead from a well-established event description (kind) to an event description lacking this property.

- Our assumptions on celebrity effects (Q6):

- The same as before: ...

- ...the event kind must be well-established in background knowledge.

- Therefore, any ordinary individual participating in the event kind formation should be wellestablished too.

\subsection{The Russian case: Focus on event realization}

- Factual ipfs (of the existential sort) have a special information structure (IS): Focus is on the event's realization, everything else is backgrounded.

- “operator IMEET MESTO v rematičeskoj pozicii” (Padučeva 1996, 36)

- "predloženija ukazyvajut na fakt osuščestvlenija dejstvija” (Šatunovskij 2009, 141; our emphasis)

- To capture this intuition, we assume with Grønn $(2003,194)$ that morphological aspect choice is sensitive to IS:

- Pf requires that the event argument is in focus, as well as the target state (cf. Grønn 2003, on target state validity).

- Factual ipf (of the existential sort) has the event argument in focus, but not the target state. $\Rightarrow$ "focus on event realization"

- For example, a standard (DRT-) semantics of the VP (a property of events) in (29a) (example from Padučeva 2006) would be the one in (29b). 
a. Anja myla pol.

A. cleaned.IPF floor

'Anja cleaned the floor.'

b. $\quad \mathrm{VP} \Rightarrow \lambda e[x \mid \operatorname{clean}(e), \operatorname{PatienT}(e, x), \mathbf{f l o o r}(x)]$

- According to Chierchia (1998), any property, "to the extent that we can impute to [it] a sufficiently regular behavior", corresponds to a kind; cf. (30) (from Chierchia).

$$
\text { For any property } P \text { and world } s, \cap P=\left\{\begin{array}{l}
\lambda s \iota P_{s} \text { is in the set of kinds } \\
\text { undefined, otherwise }
\end{array}\right.
$$

- Assuming that " $\cap$ " is defined for the property in (29b), we get (31).

$$
{ }^{n} P_{(29)}=\lambda \text { sıe }[x \mid \text { clean }(e), \operatorname{PATIENT}(e, x), e \text { in } s, \text { floor }(x)]={ }^{n} \text { floorcleaning }
$$

$\rightarrow$ Given this, we have an alternative way of stating the VP-meaning of (29a) at hand.

- By declaring an event kind discourse marker $\mathrm{e}_{k}$ in the DRS-universe, and making use of Carlson's (1977) realization relation $\mathbf{R}$, we get (32).

$$
\mathrm{VP} \Rightarrow \lambda e\left[e_{k} \mid \mathbf{R}\left(e, e_{k}\right), e_{k}={ }^{\cap} \text { floorcleaning }\right]
$$

- (32) enables us to single out the semantic condition which is in focus in factual ipfs: " $\mathrm{R}\left(\mathrm{e}, \mathrm{e}_{k}\right)$ "

- Assuming with Grønn (2003) that what is in focus goes to the assertoric part of the DRS under construction, whereas what is backgrounded goes to the presupposition part (which is indicated by subscript notation), we get (33).

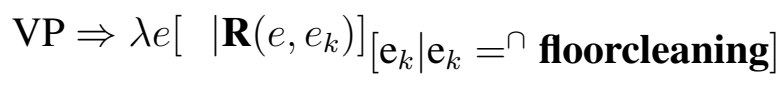

\section{$\Rightarrow$ Russian factual ipfs involve event kind formation at the level of VP due to their special IS:} Only the event realization is in focus.

\subsection{The German case: Event kind reference due to adjectivization ${ }^{8}$}

- Verbal predicates enter the derivation as predicates of event kinds.

$\Rightarrow$ The event gets instantiated only when such verbal structure is embedded under further functional structure, such as Tense/Aspect, to refer to an event token. ${ }^{9}$

- In adjectival passives, the VP is not directly embedded under Tense/Aspect but instead under an adjectival phrase (AP).

$\Rightarrow$ As a result of this category change, the underlying event associated with the verb does not get instantiated but remains in the kind domain.

- The proposal: An adjectival passive construction refers to the instantiation of a consequent state kind of an event kind. ${ }^{10}$

\footnotetext{
${ }^{8}$ This section builds on Gehrke (2011), and subsequent work.

${ }^{9}$ This is in analogy to nominal predicates, which start out as predicates of kinds and get instantiated (or realized) to enable reference to an entity token when embedded under Num(ber) (as proposed by Zamparelli 1995).

${ }^{10}$ Consequent state here is used as a cover term for result states (if the input is an accomplishment or an achievement) as well as inchoative states (if the input is a state); hence the term event here should be understood in a broader, NeoDavidsonian way to also include states. See Gehrke (to appear) for further discussion and also for a motivation to use BECOME in the formula in (34).
} 
- For example, the semantics for (34a) is given in (34b) (ignoring the contribution of Tense). ${ }^{11}$

- The consequent (i.e. result or inchoative) state associated with the verbal predicate, in turn, is embedded under Tense/Aspect and thus (can) get instantiated at some later stage.
a. Die Tür ist geschlossen.
the door is closed
'The door is closed.'
b. $\exists s_{0}, e_{k}, x_{k}\left[\operatorname{close}\left(e_{k}\right) \wedge \operatorname{BECOME}\left(s_{0}\right)\left(e_{k}\right) \wedge \operatorname{closed}\left(\mathrm{THE}\right.\right.$ DOOR, $\left.s_{0}\right)$ $\left.\wedge \operatorname{INITIATOR}\left(x_{k}, e_{k}\right)\right]$

$\Rightarrow$ German adjectival passives involve event kinds because the VP is not embedded under verbal functional structure responsible for event instantiation, but instead is adjectivized.

- Event-related modifiers have to pseudo-incorporate into the participle before adjectivisation can take place. ${ }^{12}$

- The nominals in such PPs display semantic properties of (pseudo-)incorporated nominals, such as those in (35) (Catalan, from Espinal and McNally 2011) (see also Dayal 2011):

- Obligatory narrow scope with respect to quantificational elements in the clause (35a)

- No discourse reference (e.g. no support of pronominal anaphora) (35b)

- No (ordinary restrictive token) modification, incl. relative clauses (35c)

- Stereotypicality / meaning enrichment / well-establishedness; e.g. (35a):

* There is a typical, established activity of apartment-hunting.

* This sentence cannot be used for, e.g., a child having to find the depiction of an apartment in a picture.

a. No busco pis.

not look.for.1SG apartment

= 'I am not looking for an(y) apartment.'

$\neq$ 'There is a particular apartment that I am looking for.'

b. Avui porta faldilla ${ }_{1} * \mathrm{La}_{1}$ hi vam regalar l'any

today wear.3SG skirt it.ACC her.DAT AUX.PAST.1 PL give.INF the_year passat.'

last

intended: 'Today she is wearing a skirt. We gave it to her as a present last year.'

c. *Perfi hem trobat pis, que començarem a reformar molt aviat. for final have.1SG found apartment that begin.FUT.1PL to renovate very soon intended: 'At last we have found an apartment, which we will begin to renovate soon.'

- These properties also hold for the nominals in event-related modifiers of adjectival passives, as shown in section 2, and in (36a) for obligatory narrow scope as opposed to verbal passives (36b).

a. Alle Briefe sind/waren mit einem Bleistift geschrieben.

all letters are were with a pencil written

$=$ 'All letters are/were written with a pencil.' (possibly more than one pencil)

$\neq$ 'There is/was a particular pencil that all letters are/were written with.'

\footnotetext{
${ }^{11}$ The subscripts 0 and $k$ respectively specify whether the entity in question (including states $\mathrm{s}$ and events e) refers to a token or a kind.

${ }^{12}$ A potentially similar idea underlies the proposal of Maienborn (2007a, 2011); Maienborn and Geldermann (2013), according to which event-related modifiers of adjectival participles are not regular VP modifiers but are 'integrated' into the VP (in Spec, V'). The term 'integration' is to be understood in terms of Jacobs (1993, 1999) as a special syntactic relation between a head (here: a verb) and its sister constituent (here: a PP; in Jacobs: a VP-internal argument).
} 
b. Alle Briefe wurden mit einem Bleistift geschrieben.

all letters became with a pencil written

(i) 'All letters were written with a pencil.' (possibly more than one pencil)

(ii) 'There was a particular pencil that all letters were written with.'

\section{$\Rightarrow$ Restrictions on event-related modification follow from two more general restrictions:}

- Restrictions on kind modification:

* NPs naming participants in the event, such as those in event-related by- or withphrases, cannot name actual event participants of an event particular, given that there is no event particular (no event token) to begin with.

A1, A3, A4, A5

* The event kind is not instantiated and thus lacks spatio-temporal location.

$\Rightarrow$ Ban on spatial or temporal modifiers

- Restrictions on pseudo-incorporation:

* Discourse opacity

* No token modification

* Weak/non-referentiality

* Well-establishedness

\section{Conclusion}

In the light of the results of the present paper we would qualify Carlson's (2003) statement, cited in the beginning:

- There may be circumstances under which only information about the types/properties appears within the VP and not information about (contingent) particulars.

- The VP is restricted to a pure kind-level interpretation if the verb lacks finiteness, as we argued in the case of German adjectival passives.

- It can be restricted this way, even with a finite verb, if the utterance has an existential information structure, as we argued in the case of Russian factual imperfectives.

* The descriptive part of the VP meaning, the event kind, is "stripped off" from the rest and delegated to the background.

* It still represents an essential part of the message, but it is excluded from focus, which includes event realization only.

* Being backgrounded, the event description will have to correspond to some definite/presupposed event kind.

- The bigger picture: Well-establishedness requirement on many phenomena that can be related to event kind formation at the VP level

- Russian factual ipf

- Event-related modification with German adjectival passives

- Pseudo-incorporation (cf. Dayal 2011; Espinal and McNally 2011)

- Weak definites (cf. Carlson et al. 2006; Aguilar Guevara and Zwarts 2011; Schwarz 2012) 


\section{References}

Aguilar Guevara, Ana, and Joost Zwarts. 2011. Weak definites and reference to kinds. In Proceedings of SALT 20, 179-196.

Carlson, Greg. 2003. Weak indefinites. In From NP to DP: On the Syntax and Pragma-Semantics of Noun Phrases, ed. Martine Coene and Yves D'Hulst, 195-210. Amsterdam: John Benjamins.

Carlson, Greg, Rachel Sussman, Natalie Klein, and Michael Tanenhaus. 2006. Weak definite noun phrases. In Proceedings of NELS 36, ed. Christopher Davis, Amy Rose Deal, and Youri Zabbal. Amherst, MA: GLSA.

Carlson, Gregory Norman. 1977. Reference to Kinds in English. Doctoral Dissertation, University of Massachusetts at Amherst.

Chierchia, Gennaro. 1998. Reference to kinds across languages. Natural Language Semantics 6:339-405.

Dayal, Veneeta. 2011. Hindi pseudo-incorporation. Natural Language and Linguistic Theory 29.1:123-167.

Dickey, Stephen. 2000. Parameters of Slavic Aspect. Stanford: CSLI.

Espinal, M. Teresa, and Louise McNally. 2011. Bare singular nominals and incorporating verbs in Spanish and Catalan. Journal of Linguistics 47:87-128.

Gehrke, Berit. 2011. Stative passives and event kinds. In Proceedings of Sinn und Bedeutung 15, ed. Ingo Reich, Eva Horch, and Dennis Pauly, 241-257. Universaar - Saarland University Press: Saarbrücken.

Gehrke, Berit. 2012. Passive states. In Telicity, Change, and State: A Cross-Categorial View of Event Structure, ed. Violeta Demonte and Louise McNally. Oxford University Press: Oxford.

Gehrke, Berit. 2013. Still puzzled by adjectival passives? In On Linguistic Interfaces II, ed. Raffaella Folli, Christina Sevdali, and Robert Truswell. Oxford University Press: Oxford.

Gehrke, Berit. to appear. Adjectival participles, event kind modification and pseudo-incorporation. Natural Language and Linguistic Theory.

Gese, Helga. 2011. Events in adjectival passives. In Proceedings of Sinn und Bedeutung 15, ed. Ingo Reich, Eva Horch, and Dennis Pauly, 259-273. Universaar - Saarland University Press: Saarbrücken.

Glovinskaja, Marina Ja. 1981. Obščefaktičeskoe značenie nesoveršennogo vida (formy prošedšego vremeni) ('the generalfactual meaning of the imperfective aspect (past tense forms)'). In Problemy strukturnoj lingvistiki 1978, 108-125. Moscow: Nauka.

Glovinskaja, Marina Ja. 1989. Semantika, pragmatika i stilistika vido-vremennyx form ('Semantics, pragmatics and stylistics of aspect-tense forms'). In Grammatičeskie Issledovanija: Funkcional'no-Stilističeskij Aspekt ('Grammatical Studies: Functional and Stylistic Aspect'), ed. Dmitrij N. Šmelev, 174-245. Moscow: Nauka.

Grønn, Atle. 2003. The Semantics and Pragmatics of the Russian Factual Imperfective. Doctoral Dissertation, Oslo University.

Jacobs, Joachim. 1993. Integration. In Wortstellung und Informationsstruktur, ed. Marga Reis, 62-117. Tübingen: Niemeyer.

Jacobs, Joachim. 1999. Informational autonomy. In Focus: Linguistics, Cognitive, and Computational Perspectives, ed. Peter Bosch and Rob van der Sandt, 56-81. Cambridge: Cambridge University Press.

Kratzer, Angelika. 1994. The event argument and the semantics of Voice. Ms. University of Massachusetts at Amherst.

Kratzer, Angelika. 2000. Building statives. Ms. University of Massachusetts at Amherst.

Maienborn, Claudia. 2003. Event-internal modifiers: Semantic underspecification and conceptual interpretation. In Modifying Adjuncts, ed. Ewald Lang, Claudia Maienborn, and Catherine Fabricius-Hansen, 475-509. Berlin: de Gruyter.

Maienborn, Claudia. 2007a. Das Zustandspassiv: Grammatische Einordnung - Bildungsbeschränkung - Interpretationsspielraum. Zeitschrift für germanistische Linguistik 35:83-144.

Maienborn, Claudia. 2007b. On Davidsonian and Kimian states. In Existence: Semantics and Syntax, ed. Ileana Comorovski and Klaus von Heusinger, 107-130. Dordrecht: Springer.

Maienborn, Claudia. 2011. Strukturausbau am Rande der wörter: Adverbiale Modifikatoren beim Zustandspassiv. In Sprachliches Wissen zwischen Lexikon und Grammatik, ed. Stefan Engelberg, Anke Holler, and Kristel Proost, 317-343. Berlin: de Gruyter.

Maienborn, Claudia, and Sascha Geldermann. 2013. 'Expertengeprüft' und 'vom Experten geprüft': Zur Semantik von Nomen-Partizip II-Komposita und ihrer präpositionalen Partner. In Interfaces of Morphology: A Festschrift for Susan Olsen, ed. Holden Härtl, 127-161. Berlin: Akademie Verlag.

Padučeva, Elena V. 1996. Semantičeskie Issledovanija ('Semantic Studies'). Moscow: Škola 'Jazyki russkoj kul'turoj'.

Padučeva, Elena V. 2006. Review of: Groenn, A. (2004), The Semantics and Pragmatics of the Russian Factual Imperfective. Russian Linguistics 30.2:293-302.

Rapp, Irene. 1996. Zustand? Passiv? Überlegungen zum sogenannten "Zustandspassiv". Zeitschrift für Sprachwissenschaft 15.2:231-265.

Rapp, Irene. 1997. Partizipien und semantische Strukur: Zu passivischen Konstruktionen mit dem 3. Status. Tübingen: Stauffenburg.

Schwarz, Florian. 2012. How weak and how definite are Weak Definites? Ms. University of Pennsylvania.

von Stechow, Arnim. 1998. German participles II in Distributed Morphology. Ms. Unversity of Tübingen.

Vogeleer, Svetlana. 1993. La référence nominale et l'emploi de l'imperfectif constatif dans les questions oui-non et wh- en russe. Linguisticae Investigationes 37.1:223-237.

Šatunovskij, Il'ja B.Problemy russkogo vida ('Problems of Russian Aspect'). Moscow: Jazyki slavjanskix kul'tur.

Zamparelli, Roberto. 1995. Layers in the Determiner Phrase. Doctoral Dissertation, University of Rochester. 